LAERE MIDDEL ODK

\title{
Implementering af læringsplatforme og kulturelle logikker
}

Af Andreas Lindenskov Tamborg og Benjamin Brink Allsopp, Aalborg Universitet

Korrekt citering af denne artikel efter APA-systemet (American Psychological Association System, 6th Edition): Tamborg, A. L. \& Allsopp, B. B. (2019). Implementering af læringsplatforme og kulturelle logikker.

Learning Tech - Tidsskrift for læremidler, didaktik og teknologi, (6), 82-105. DOI 10.7146/It.v4i6.110853 


\section{Abstract}

Implementering af læringsplatforme er en kompleks proces, der involverer mange forskellige aktører. I denne artikel ser vi nærmere på, hvordan disse forskellige aktører forholder sig til læringsplatformene, og hvordan relationer mellem aktørers forholdemåder indvirker på betingelserne for at implementere læringsplatforme. Empirisk er artiklen baseret på empiri fra fremtidsværksteder afholdt i forbindelse et større forskningsog udviklingsprojekt, som vi bearbejder ved hjælp af en kortlægningsproces understøttet af den visuelle notationsteknik, Arcform. Disse kortlægninger analyseres efterfølgende med Nielsens (2012) logikbegreb for at identificere aktørers forholdemåder til platforme og deres indbyrdes relation. Artiklen afsluttes med en diskussion af betydningen af denne indbyrdes relation for implementering af læringsplatforme og af bud på, hvordan implementering af læringsplatforme i lyset af artiklens konklusioner kan håndteres på skoler.

The implementation of digital learning platforms can be a complex process as it involves change for multiple stakeholders such as teachers, school managers and staff from the municipality. This paper draws on video observations from workshops held at two schools in a project intended to support implementation. The aim of this paper is to map the stakeholders' beliefs about the platforms and their implementation, to identify cultural logics underlying these beliefs and to investigate how these affect opportunities for implementing the platforms. 


\title{
Implementering af læringsplatforme og kulturelle logikker
}

\author{
Indledning
}

Denne artikel omhandler implementeringen af læringsplatforme, der i øjeblikket pågår på de danske folkeskoler. Litteraturen om anvendelse af digitale læringsplatforme i uddannelseskontekster peger på den ene side på, at digitale læringsplatforme har potentialer til at understøtte elevers læring (Edmunds \& Hartnett, 2014; Lu \& Law, 2011; Liu \& Cavanaugh, 2011; Psycharis, Chatazoglidis \& Kalogiannakis, 2013; Misfeldt, 2013). På den anden side fremhæver flere studier også, at implementering af læringsplatforme er en kompleks proces (Conrad \& Graham, 2015; Underwood \& Stiller, 2013). Denne kompleksitet er blandt andet relateret til de bekymringer, implementeringen kan fremkalde blandt centrale aktører på skoler såsom det pædagogiske personale, skoleledere og administrative medarbejdere (Misfeldt \& Tamborg, 2016; Underwood \& Stiller, 2013). I den sammenhæng viser studier, at der blandt pædagogisk personale er tendens til, at digitale læringsplatforme associeres med en øget standardiseret tilgang til undervisning på bekostning af professionel dømmekraft (Lochner, Conrad \& Graham, 2015). I tillæg hertil udviser skoleledere bekymringer om, hvorvidt digitale platforme fører nye øgede krav om besparelser og "accountability" med sig (Selwyn, 2012). Disse bekymringer er i sig selv en væsentlig hindring for at indfri læringsplatformenes potentialer. Det bliver imidlertid ikke mindre komplekst af, at forskellige aktører oplever forskellige typer af bekymringer i forbindelse med implementeringsprocessen. En mulig forklaring på disse forskelle er, at bekymringerne udtrykker forskellige typer af mål og prioriteringer i implementeringsprocessen. Sådanne forskelle i mål og prioriteringer kan have afgørende betydning for aktørernes måder at indgå i implementeringsprocessen, og det er let at forestille sig, at de kan skabe sammenstød mellem de involverede aktørgrupper. I denne artikel sætter vi fokus på, hvordan aktørgrupperne involveret i implementeringsprocessen forholder sig til platformene og den indbyrdes relation mellem disse forhol- 
demåder, samt hvilken betydning denne relation har for implementeringsprocessen. I denne artikel har vi valgt at fokusere på lærere, skoleledere og skolekonsulenter fra forvaltninger. Det empiriske grundlag for at undersøge dette er baseret på observationer fra fremtidsværksteder afholdt på to skoler i projektet "Anvendelse af Digitale Læringsplatforme og Læremidler". I artiklen anvender vi en visuel notationsteknik kaldet Arcform (Allsopp, 2013) til at synliggøre og fremanalysere aktørernes måder at forholde sig til platformene, som de blev udtrykt ved disse fremtidsværksteder. Gennem Nielsens (2012) begreb, kulturelle logikker, undersøger vi dernæst mønstre i de underliggende prioriteringer, som forholdemåderne repræsenterer. Vi afslutter artiklen med en diskussion af, hvordan forskelle mellem sådanne forholdemåder og prioriteringer indvirker på betingelserne for implementering af læringsplatforme. Afslutningsvis giver vi et bud på, hvordan artiklens resultater kan anvendes til at understøtte den igangværende implementering af læringsplatforme på de danske folkeskoler.

\section{Kontekst}

Denne artikel udspringer af et større forsknings- og udviklingsprojekt om implementering og brug af digitale læringsplatforme finansieret af den fællesoffentlige indsats "It i folkeskolen", som Undervisningsministeriet/Styrelsen for It og Læring, KL og Digitaliseringsstyrelsen står bag. Projektet blev gennemført fra 2016-2017 af et konsortium bestående af Aalborg Universitet, Syddansk Universitet, Alexandra Instituttet, UCSYD, Professionshøjskolen Absalon og UCL Erhvervsakademi og Professionshøjskole. Projektet var et brugerinvolverende forskningsprojekt, der gennem workshops afholdt på i alt 15 skoler understøttede og undersøgte implementeringen af digitale læringsplatforme. Projektet blev gennemført af et hold bestående af 30 forskere og konsulenter fra de involverede institutioner, der i samarbejde med det pædagogiske personale på de 15 skoler udviklede, designede og planlagde nye måder at anvende læringsplatformene på på de pågældende skoler. Dette foregik på workshops afholdt på hver af de 15 skoler. Disse workshops var baseret på henholdsvis fremtidsværksteder (Jung \& Müller, 1984) og designworkshops. Fremtidsværkstederne bestod af en kritikfase, en utopifase og en virkeliggørelsesfase, der alle var faciliteret af forskere og konsulenter fra projektet. I kritikfasen fik 
det pædagogiske personale mulighed for at udtrykke deres kritik af eksisterende praksisser eller uhensigtsmæssige designs af læringsplatformene. I utopifasen var formålet, at fik de mulighed for at udtrykke deres visioner og drømme for, hvordan læringsplatformene ideelt set kunne bruges på meningsfulde måder. Disse visioner blev formuleret som idéforslag, og det pædagogiske personale skulle efterfølgende stemme om, hvilke af disse idéer de ville arbejde med at videreudvikle og implementere i den efterfølgende virkeliggørelsesfase. Afhængig af deltagerantallet på den enkelte skole valgte de at gå videre med 1-4, idéer. Efter, at deltagerne var nået til enighed om valget af idéer, gik virkeligg ørelsesfasen i gang. Denne fase blev gennemført med inspiration fra designtænkning, hvor personalet gruppevis arbejdede med at konkretisere og kvalificere den pågældende idé samt udvikle en plan for en praktisk afprøvning af den. Disse idéer omfattede bl.a. forslag om pædagogiske/didaktiske tiltag samt forslag om, hvordan elevers forældre kunne instrueres i at tilgå information på læringsplatformen.

Det empiriske grundlag for denne artikel udgøres af diskussioner blandt lærere, skoleledere og kommunale konsulenter, som de udspillede sig på disse workshops. Inden vi beskriver dataindsamling og empiri nærmere, vil vi dog først introducere den teoretiske tilgang, vi anvender i denne artikel.

\section{Teoretisk tilgang}

I vores analyser anvender vi Nielsens begreb, dynamisk stabilitet (også kaldet kulturelle logikker), der oprindeligt blev udviklet til at undersøge teamsamarbejde blandt lærere (2012). Nielsen udviklede dette begreb til at beskrive det tilsyneladende modsætningsfyldte fænomen, at læreres teamsamarbejde på én gang indeholder et statisk og et dynamisk element. Ifølge Nielsen involverer læreres teamsamarbejde på daglig basis en bred variation af opgaver, aktiviteter og mål. Denne mangfoldighed af omskiftelige opgaver, aktiviteter og mål udgør det dynamiske element i læreres arbejde. Samtidig observerede Nielsen en underliggende regularitet i de principper og prioriteringer, som lærerne håndterede disse dynamiske opgaver på. Denne regularitet definerer Nielsen som en kulturel logik, der dækker over de underliggende stabile prioriteringer bag lærernes handlinger.

Kulturelle logikker kan betragtes som måder at se verden på og har betydning for, hvordan en (lokalt afgrænset) gruppe af ak- 
tører handler. Ifølge Nielsen (2012) er kulturelle logikker vanskelige for udefrakommende at ændre, fordi de ofte afspejler, hvad den pågældende aktør (eller aktørgruppe) opfatter som værende vigtigt. I denne tænkning vil aktører derfor være mere tilbøjelige til at anvende læringsplatforme og indgå i implementeringen af læringsplatforme på deres kulturelle logiks betingelser, end de er tilbøjelige til grundlæggende at ændre deres prioriteringer, blot fordi læringsplatforme nu er en del af skolens hverdag.

Som tidligere beskrevet er formålet med denne artikel at undersøge, hvordan aktører forholder sig til læringsplatformene, og hvilken indvirkning den indbyrdes relation mellem disse forholdemåder har på implementeringen af læringsplatforme. Med Nielsens (2012) begreb konceptualiserer vi dermed aktørernes forholdemåder som kulturelle logikker. I artiklen undersøger vi således aktørgruppernes kulturelle logikker i relation til læringsplatformene for dernæst at diskutere den indbyrdes relation mellem disse, og hvordan denne relation indvirker på betingelserne for implementering af platformene. Disse analyser foretager vi på to skoler, der deltog i projektet. Selvom Nielsen (2012) oprindeligt udviklede dette begreb til at analysere mønstre i én gruppe af aktører, nemlig lærere, har begrebet imidlertid også vist sig at være anvendeligt til at beskrive og undersøge logikker blandt andre typer aktører (fx skoleledere og konsulenter, se fx Tamborg, Allsopp, Fougt \& Misfeldt, 2017 og Tamborg \& Allsopp, 2017). I en kontekst, hvor forskellige aktørgrupper samarbejder, har begrebet den fordel, at det gør det muligt at få øje på forskelle i kulturelle logikker, der optræder blandt forskellige aktørgrupper involveret i fx implementeringsprocesser. Da implementering af læringsplatforme både vedrører skoleledere (inklusiv pædagogiske ledere), kommunale konsulenter og lærere m.fl., har vi fundet dette begreb særligt anvendeligt til at belyse de perspektiver på læringsplatforme, der kan identificeres blandt disse aktørgrupper. Denne artikel er således rettet mod at besvare følgende spørgsmål:

\section{Hvilke kulturelle logikker kan der identificeres blandt aktørerne på fremtidsværkstederne, og hvilke implikationer har disse logikkers indbyrdes relation for betingelserne for den lokale implementering af læringsplatformene?}


I det følgende afsnit beskriver vi nærmere, hvilke typer af empiri vi anvender til at besvare dette spørgsmål, og hvilke metoder vi tager i brug for at behandle denne data.

\section{Empiri og metode}

Vores empiriske udgangspunkt for at besvare spørgsmålet formuleret ovenfor består af observationer fra to fremtidsværksteder afholdt på to skoler, der begge har deltaget i projektet, som tidligere er nævnt i denne artikel. Af etiske hensyn er både skolerne og de deltagende aktører anonymiserede, og vi benævner skolerne som henholdsvis Skole 1 og Skole 2. Fremtidsværkstederne afholdt på de to skoler var begge af ca. seks timers varighed og blev faciliteret af to forskere, hvoraf den ene er forfatter til denne artikel. På Skole 1 deltog tre lærere og to skoleledere, mens seks lærere og en konsulent fra forvaltningen deltog på Skole 2. Under fremtidsværkstedet var facilitatorernes rolle at guide deltagerne gennem fremtidsværkstedets faser. Facilitatorernes fungerede desuden som observatører af fremtidsværkstedet og dokumenterede gennem feltnoter, hvordan aktørerne forholdt sig til platformen, og hvilke visioner og kritikker der kom til udtryk. Foruden disse observationsnoter blev seancerne også videofilmet.

Denne empiri fra fremtidsværkstederne indeholdt et væld af ytringer og meningstilkendegivelser fra de deltagende aktører, hvilket gør det til en kompliceret affære at identificere stabile kulturelle logikker blandt de deltagende aktører. Udfordringen bestod ikke alene i at udlede, hvilket synspunkt en bestemt ytring eller meningstilkendegivelse repræsenterede, men den bestod også i at vurdere, i hvilken udstrækning dette synspunkt var repræsentativt for den pågældende aktørgruppe (fx lærere). For at understøtte undersøgelsen af aktørernes kulturelle logikker, anvendte vi det visuelle notationsværktøj Arcform (Allsopp, 2013). Vi anvendte dette værktøj til visuelt at kortlægge vores forståelse af aktørernes synspunkter, da denne visualiseringsteknik åbnede for diskussion og analyse af aktørernes kulturelle logikker. Arbejdet med at konstruere kortet foregik ved, at vi gennemlæste observationsnoter fra kritikfasen og fantasifasen på de afholdte fremtidsværksteder. Ytringerne fra disse faser gav os både information om aktørernes oplevede uhensigtsmæssigheder i forbindelse med platformen og om deres visioner og drømme om, hvordan gode praksisser med platformene kunne se ud. De afholde fremtidsværksteder giver ikke nødvendigvis 
indblik i aktørgruppernes daglige praksisser og de kulturelle logikker, der kan observeres her. Fremtidsværkstedets kritik- og fantasifaser skabte imidlertid rum for, at aktørgrupperne kunne udtrykke deres prioriteringer og mål direkte. Dette skabte et gunstigt grundlag for at fremanalysere kulturelle logikker, fordi disse netop omfatter aktørers prioriteringer og mål. Efter at have gennemlæst observationsnoterne konstruerede vi i fællesskab et tentativt kort. I de tilfælde, hvor observationsnoterne ikke indeholdt tilstrækkelig dokumentation til at afdække et konsistent billede af en aktørgruppes kulturelle logik, så vi dele af videooptagelserne igennem for at finde yderligere information. Dette forløb som en iterativ vekselvirkning mellem at nuancere kortene og konsultere datakilderne. I afsnittet nedenfor beskriver vi Arcform og vores anvendelse af værktøjet nærmere.

\section{Visualisering gennem Arcform}

Arcform (Allsopp, 2013) er en visuel notationsteknik, der har lighedstræk med flere netværksnotationsteknikker. Ligesom i andre netværksnotationsteknikker anvendes knuder som repræsentation for objekter (fx aktører), og pile anvendes til at repræsentere objekters relation(er) til hinanden ved at forbinde disse til hinanden. Arcform adskiller sig fra størstedelen af øvrige netværksnotationsteknikker ved, at betydningen af en relation mellem to knuder kan fastholdes i pilen alene, og at pile også kan forbindes til og/eller fra andre pile. Pile kan også pege fra eller på sig selv for eksempelvis at udtrykke intransitive relationer. I Arcform navngives knuder og pile, så de kan læses sekventielt som grammatisk normale sætninger. Figur 1 nedenfor viser et eksempel på, hvordan objekter og deres relation kan udtrykkes i Arcform. Figuren repræsenterer sætningen "Lærere forsøger at anvende læringsplatforme", som kan læses fra navnene i sekvensen. 


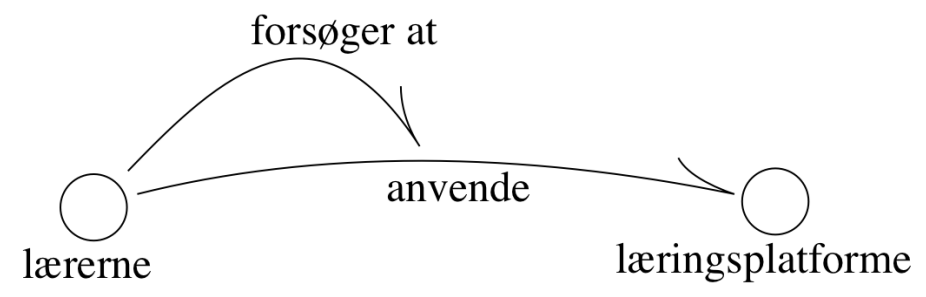

Hele betydningen af denne sætning er lagret i pilen navngivet "forsøger at", der kan genbruges af andre pile, der forbinder den til andre objekter eller sætninger. Princippet er eksemplificeret i pilen navngivet "anvende(r)", som repræsenterer sætningen "lærere anvender læringsplatforme", der er anvendt som en del af den sætning lagret i pilen navngivet "forsøger at". Den rekursive genanvendelse af meninger gør det muligt at kortlægge komplekse relationssystemers indbyrdes relation til hinanden på en forholdsvis overskuelig måde. Hvis en skoleleder eksempelvis har en bestemt holdning til, om lærere forsøger at bruge platforme, kan dette udtrykkes ved at genbruge pilen "forsøger at" som udgang eller destination for en anden pil. Arcform gør det muligt at tilføje et ubegrænset antal udtryk, der genbruger eksisterende knuder og pile.

Fordelen ved denne tilgang er, at produktet af visualiseringen med Arcform er kort-lignende. Dette kan forstås ved, at vi danner overblik over et plan i stedet for at navigere i en enkelt sekvens af ord i paragraffer af tekst (som man fx gør det ved kodning af data). Dette kan også forstås mere grundlæggende med konceptet unitokenality (Allsopp, 2013). Dette begreb indebærer, at væsentlige meninger kun behøver at repræsenteres én gang, selvom de bruges mange gange. Denne egenskab har flere lighedstræk med de fleste korttyper, som vi kender dem fra fx landkort. Et landkort over Danmark er unitokenal, fordi lokationer, som $\mathrm{x}$ byen København, kun optræder ét sted. Samtidig har kortet en rumlighed, der gør det muligt at se og udforske Københavns omgivelser ved at kigge på kortet (fx hvilke veje, der fører til byen, og hvilke byer, der ligger ved siden af). Arcformkort deler denne unitokenality med kort på den måde, at 
objekter (som fx "lærerne") også kun optræder ét sted på kortet. $\mathrm{Al}$ information om "lærerne" kan læses ud fra de streger, som er forbundet til knuden, der repræsenterer "lærerne". Arcform gør det således muligt at organisere en stor mængde information i en overskuelig repræsentationsform, hvilket er netop det, vi havde behov for for at bevæge os fra diskussioner på fremtidsværksteder til en organisering af denne data.

Arcform tillader alle former for subjekter og objekter at indgå i kort og at lade handlinger og synspunkter udgå fra både objekter og subjekter. Dette betyder ikke, at der i Arcform ligger en antagelse om, at objekter (som fx læringsplatforme) kan handle på samme måde, som subjekter (fx en lærer) kan. Den, der producerer kortet, har imidlertid friheden til at konstruere kortet ud fra en sådan antagelse og fremstille kort, hvor læringsplatforme eller andre non-humane aktører tildeles agens på lige fod med humane aktører. Genstanden for vores analyse er imidlertid skolelederes, konsulenters og læreres prioriteringer og mål i relation til læringsplatforme. Af denne årsag er disse aktørgrupper de eneste, der handler og har synspunkter i vores kort. Når vi viser, at lærere $\mathrm{fx}$ forbinder læringsplatforme med bestemte typer af undervisning, hævder vi dermed ikke, at platformen faktisk er befæstet med sådanne prioriteringer, men at det er sådan, lærere tolker læringsplatforme.

\section{Fra konstruktion af kort til analyse}

Med udgangspunkt i vores empiri anvendte vi Arcform til at kortlægge synspunkter blandt aktørerne tilstede ved fremtidsværkstederne og de indbyrdes relationer mellem disse. Som angivet ovenfor var formålet med denne proces at bearbejde empirien, så den efterfølgende begrebsbårne analyse af aktørernes kulturelle logikker var lettere at tilgå, end hvad der ellers ville have været tilfældet. Dette betyder, at bevægelsen fra data til analyse i denne artikel har involveret to trin:

1. Fra data til kort.

2. Fra kort til begrebsbårne analyser.

For at skabe transparens i vores arbejde med begge disse processer, har vi valgt at beskrive dem separat. Først vil vi beskrive empirien og vores tolkninger af stabile mønstre i aktørernes måder at forholde sig til platformene, samt hvordan vi har repræ- 
senteret disse med Arcform. I dette afsnit vil vi bringe empiriske eksempler på udsagn eller observationer, der underbygger vores tolkninger. Dernæst vil vi aktivere Nielsens begreb om kulturelle logikker til at undersøge de stabile underliggende prioriteringer, der kan fremanalyseres i disse forholdemåder. Denne analyse vil sidenhen danne grundlag for en diskussion af relationen mellem aktørernes måder at forholde sig til læringsplatformene på de to skoler, og hvilken betydning disse har for implementering af læringsplatformene. I det følgende afsnit vil vi fokusere på at beskrive bevægelsen fra data til kort, hvor vi behandler de to skoler separat.

\section{Synspunkter blandt aktørerne}

\section{Skole 1}

\section{Skoleledere på Skole 1}

På Skole 1 deltog en skoleleder, en pædagogisk leder med ansvar for skolens digitale læringsplatform samt 4 lærere. Under diskussionerne på fremtidsværkstedet på denne Skole 1 satte de tilstedeværende skoleledere ikke spørgsmålstegn ved platformenes potentielle værdi. Under workshoppene kom det til udtryk ved, at de generelt var uforstående over for lærere, der ikke så værdien i platformene, da det for lederne var åbenlyst, at platformene gjorde læreres arbejde lettere. Dette er eksemplificeret ved følgende udsagn, der blev ytret af en af skolelederne i kritikfasen:

99

Men man er nødt til at bruge den [læringsplatformen] over længere tid, hvis den skal have en værdi. Vi har mange dygtige og meget kompetente lærere på vores skole, men det er ikke alle, der er lige villige til at prøve noget nyt. Og jeg har altså vanskeligt ved at acceptere, at folk helt afviser at prøve det af for at se, om det virker. For jeg tror virkelig på, at platformen faktisk kan hjælpe lærerne og effektivisere nogle af deres arbejdsprocesser.

Som det fremgår ovenfor var skolelederne af den overbevisning, at platformene havde egenskaber, der kunne hjælpe, understøtte og effektivisere lærernes daglige arbejde. Dette synspunkt fremgår også i nedenstående udtalelse, hvor en af lederne peger på, at lærere kan dele forløb gennem platforme og på den måde spare tid: 
For mig at se tjener en læringsplatform tre formål. Det ene er at skabe lærerens bevidsthed om, hvad de vil med deres undervisning, to at eleverne får klarhed over, hvad de skal lære, tre fordi det er transparent, kan vi trække ganske gratis hos hinanden og stjæle hos hinanden lige så meget, man vil, så man kan spare noget tid i nogle andre sammenhænge og koncentrere sig om evalueringsdelen.

Synspunktet, at læringsplatformene kan hjælpe lærerne, er afbildet i Figur 2 ved pilen "kan hjælpe", der udgår fra knuden "læringsplatforme" pegende mod knuden "lærerne". Det første af citaterne ovenfor viser også skoleledernes perspektiv, at lærernes oplevelse af platformens ringe værdi var relateret til, at de ikke i tilstrækkeligt omfang aktivt havde forsøgt at anvende læringsplatformen. I figuren er dette synspunkt repræsenteret af pilen navngivet "ikke".

Figur 2. Denne version af Arcform-kortet viser skoleledernes synspunkt, at lærerne ikke forsøger at anvende platformene, og at platformene kan hjælpe lærerne, hvis de forsøger at anvende dem.

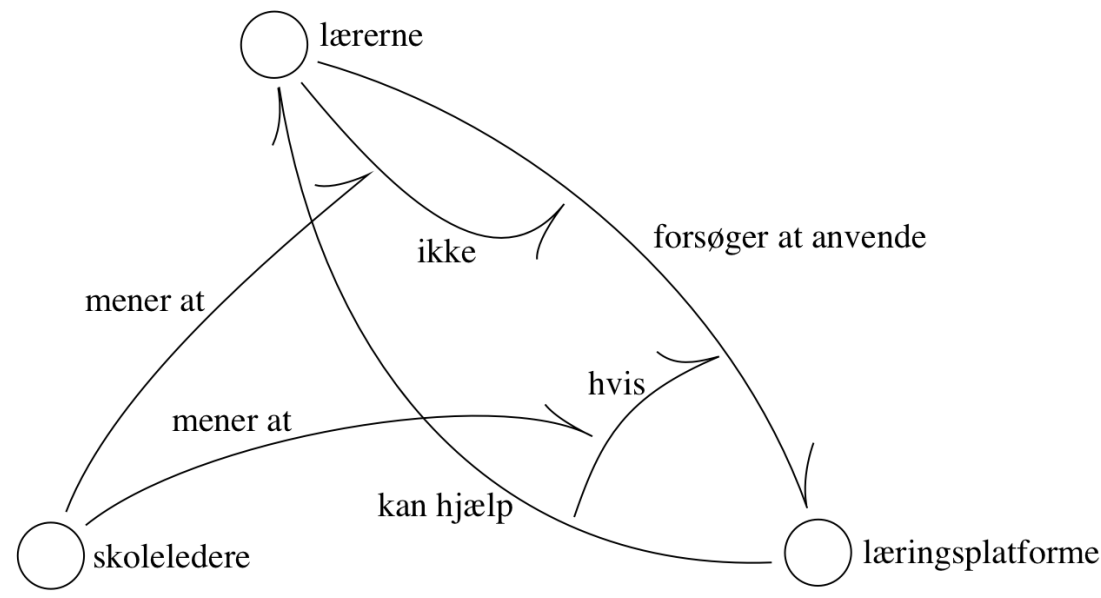


Synspunktet udtrykt og repræsenteret i kortet er således, at læringsplatformene kan hjælpe lærerne, men at det forudsætter, at de investerer tid i at lære teknologien at kende. I figuren er dette synspunkt udtrykt med forbindelsen navngivet "hvis", der angiver den forudsætning, at lærerne faktisk forsøger at anvende platformene. Som vi skal se i det følgende, udtrykte lærerne til stede ved fremtidsværkstedet, ikke overraskende, andre synspunkter.

\section{Lærere på Skole 1}

Lærerne på Skole 1 var overordnet af den overbevisning, at læringsplatformene ikke var et hensigtsmæssigt redskab, og de udtrykte relativt direkte modvilje mod at bruge den. Det er illustreret af følgende observationer, som blev nedfældet under afviklingen af fremtidsværkstedet:

99

De tre lærere udtrykte overvejende modvilje mod læringsplatformen og den læringsmålstyrede didaktik, de associerede med teknologien. De var desuden af den overbevisning, at den fokuserede uforholdsmæssigt meget på dataindsamling og evaluering, mens den ikke rummede den ugeplans-agtige funktion, der giver elever og forældre oplysninger, som hvornår de skal huske idrætstøj eller engelskbøger, og som de alle tre mente var langt mere væsentligt for forældre at vide, end hvilke læringsmål eleverne aktuelt skal arbejde mod at opnå.

Som det fremgår af citatet ovenfor, fremførte lærerne flere årsager til, at de ikke ville anvende platformen. Deres væsentligste kritik af platformen gik imidlertid på, at læringsplatformen efter deres overbevisning prioriterede læringsmål over indhold. Dette synspunkt blev udtrykt meget direkte af en af de deltagende lærere, hvilket følgende citat er et eksempel på:

99

Hele den didaktiske ramme i læringsplatformen med fokus på læringsmål er alt for snæver. En af de bærende idéer bag platformen er jo, at vi skal fokusere på læringsmål i stedet for indhold. Men for mig er indholdet uden tvivl det vigtigste, og det er også indholdet, der fastholder elevernes motivation. Og jeg tror ikke på, at vi altid er i stand til at forudsige og definere læringsudbyttet på forhånd i en læ- 
ringsplatform. Så som jeg ser det, skal læringsplatformene grundlæggende kunne noget andet, end de kan nu."

I observationsnoterne taget under workshoppen fremgår det også, at facilitatorerne bemærkede denne skepsis og betragtede den som en potentiel udfordring for, at interventionen på skolen skulle blive en succes:

99

Hos to lærere er deres didaktiske grundsyn en potentiel udfordring [for succesen af implementering], da de associerer læringsplatformen med en didaktik, de grundlæggende er uenig i [læringsmålstyret undervisning].

I Figur 3 nedenfor er dette synspunkt udtrykt ved pilen navngivet "mener at", der udgår fra knuden "lærer" og peger mod pilen navngivet "prioriterer læringsmål over indhold" og med stregen "fordi", der peger fra "ikke" til "mener at".

Figur 3. En version af Arcform-kortet, der viser, at lærerne ikke forsøger at bruge platformene, fordi de mener, at platformen prioriterer læringsmål over indhold.

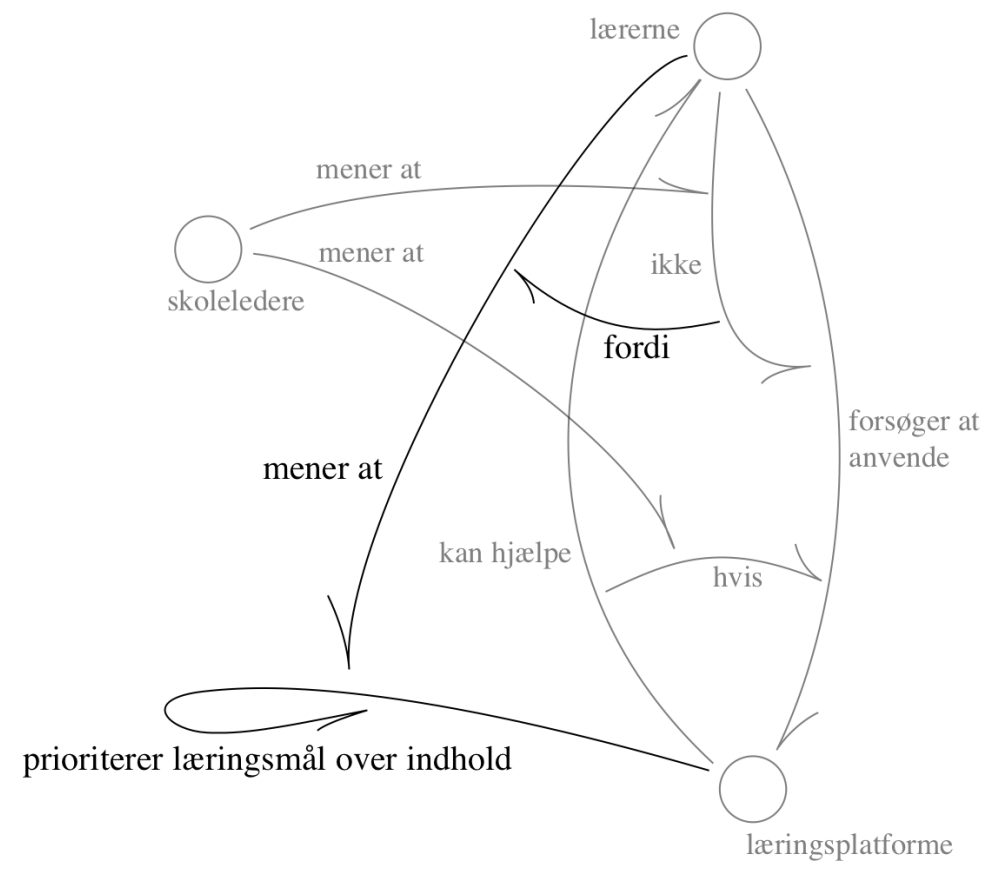

94 Learning Tech 06 | Den digitale læringsplatform i Danmark 


\section{Skole 2}

\section{Kommunal konsulent fra Skole 2}

På fremtidsværkstedet afholdt på Skole 2 deltog 7 lærere og en kommunal konsulent. Dialogerne i denne seance kredsede en stor del af tiden om de tekniske kompetencer, de oplevede som nødvendige for at kunne bruge platformen. Under fremtidsværkstedet gav lærerne løbende udtryk for deres oplevelse af ikke at have den fornødne viden om platformens funktioner til at anvende den, mens konsulenten derimod havde indgående kendskab til mulighederne i platformen og dens funktionalitet.

Dette fremgår af følgende observationer, der blev nedfældet under fremtidsværkstedet:

99 Lærerne ved meget lidt om, hvad platformen kan og ikke kan, og de virker meget interesserede i at lære mere af konsulenten. Konsulenten er meget åben overfor at dele sin viden med lærerne, og efter seancen aftaler de, at konsulenten skal hjælpe lærerne med at planlægge et forløb i platformen.

På kortet i Figur 4 er dette repræsenteret ved knuden navngivet "Tekniske kompetencer" og forbindelsen "har ikke", mens konsulentens tekniske kompetencer er repræsenteret gennem forbindelsen med navnet "har". Det forhold, at konsulenten var villig til at hjælpe og støtte lærerne i deres brug af platformen, er udtrykt i forbindelsen "til at", der peger mod forbindelsen "understøtte(r) når". 
Figur 4. Viser, at konsulenterne har tekniske kompetencer til at understøtte lærerne $i$ at forsøge at anvende platforme, og at konsulenterne samtidig understøtter VFL.

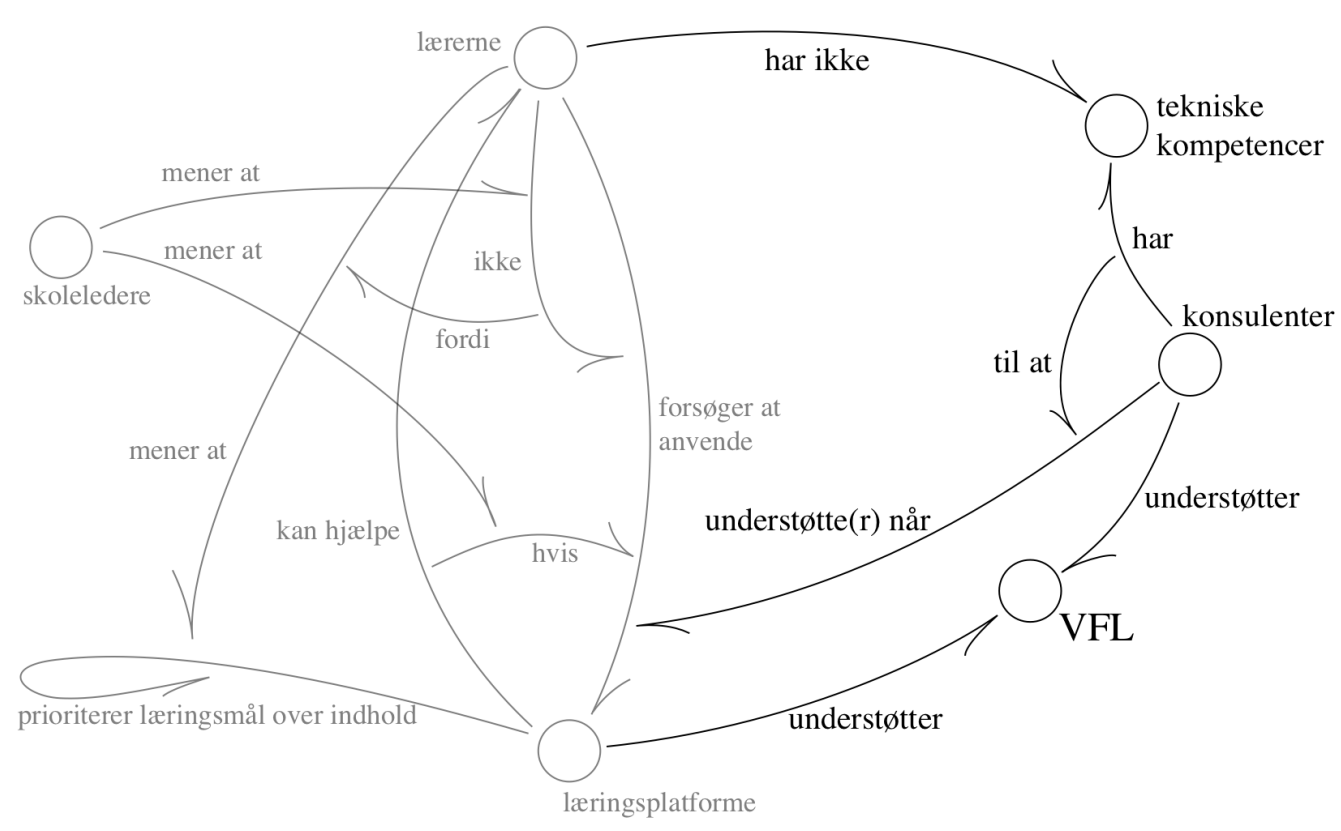

Skole 2 befandt sig i en kommune, hvor princippet "Vurdering for Læring" (VFL) var implementeret på alle skoler, inklusiv Skole 2. VFL er en didaktisk tilgang, der kan anvendes af lærere som et systematisk værktøj til at arbejde med formativ evaluering med henblik på at understøtte elevers læring (Slemmen, 2016). VFL indgår også i kortet i Figur 4 og optræder som en knude med navnet "VFL". Den kommunale konsulent, der var tilstede ved fremtidsværkstedet, støttede VFL og udtrykte, at han så klare potentialer i at fastholde dette princip i lærernes arbejde med platformene. Dette fremgår af følgende udtalelse ytret af konsulenten:

99 Vi har snakket om, at vi har mange indsatser i gang her på skolen. Vi kører med noget i hele kommunen, der hedder Vurdering for Læring og så er vi med i Videnproduktion, og vi vil gerne, at vi kunne få det ind i MinUddannelse. På samme sted, men også at det vi gør skal give mening for eleverne. Når vi skal have sådan en platform, så skal vi jo bruge den der, hvor det giver mening. 
Sidstnævnte fremgår af kortet i Figur 4 gennem de to forbindelser navngivet "understøtter".

\section{Lærere på Skole 2}

Lærerne på denne skole tilføjede nye perspektiver på platformene, der er væsentlig forskellige fra dem på Skole 1. Ligesom konsulenten var lærerne fra Skole 2 hurtige til at tilkendegive et $\emptyset$ nske om at fastholde brugen af VFL. Dette ønske blev udtrykt af lærerne flere gange under fremtidsværkstedet. Det følgende citat viser et eksempel på, hvordan en af lærerne omtalte VFL i visionsfasen:

99 Vi har brug for et sted, hvor vi kan arbejde med VFL. Og jeg synes, det er vigtigt, at vi eksperimenterer med, hvordan og $\mathrm{i}$ hvilken udstrækning platformen kan levere sådan et sted.

Dette synspunkt er angivet ved en ny pil navngivet "understøtter", der udgår fra knuden "lærere" til knuden "VFL" i Figur 5 nedenfor. I denne sammenhæng bekræftede lærerne desuden, at de var villige til at forsøge at bruge læringsplatformen, hvilket er angivet med pilen navngivet "er villige til at". Denne velvilje var tæt relateret til deres motivation til at afprøve, om VFL kunne integreres i platformen. Dette er angivet med stregen navngivet "fordi". 


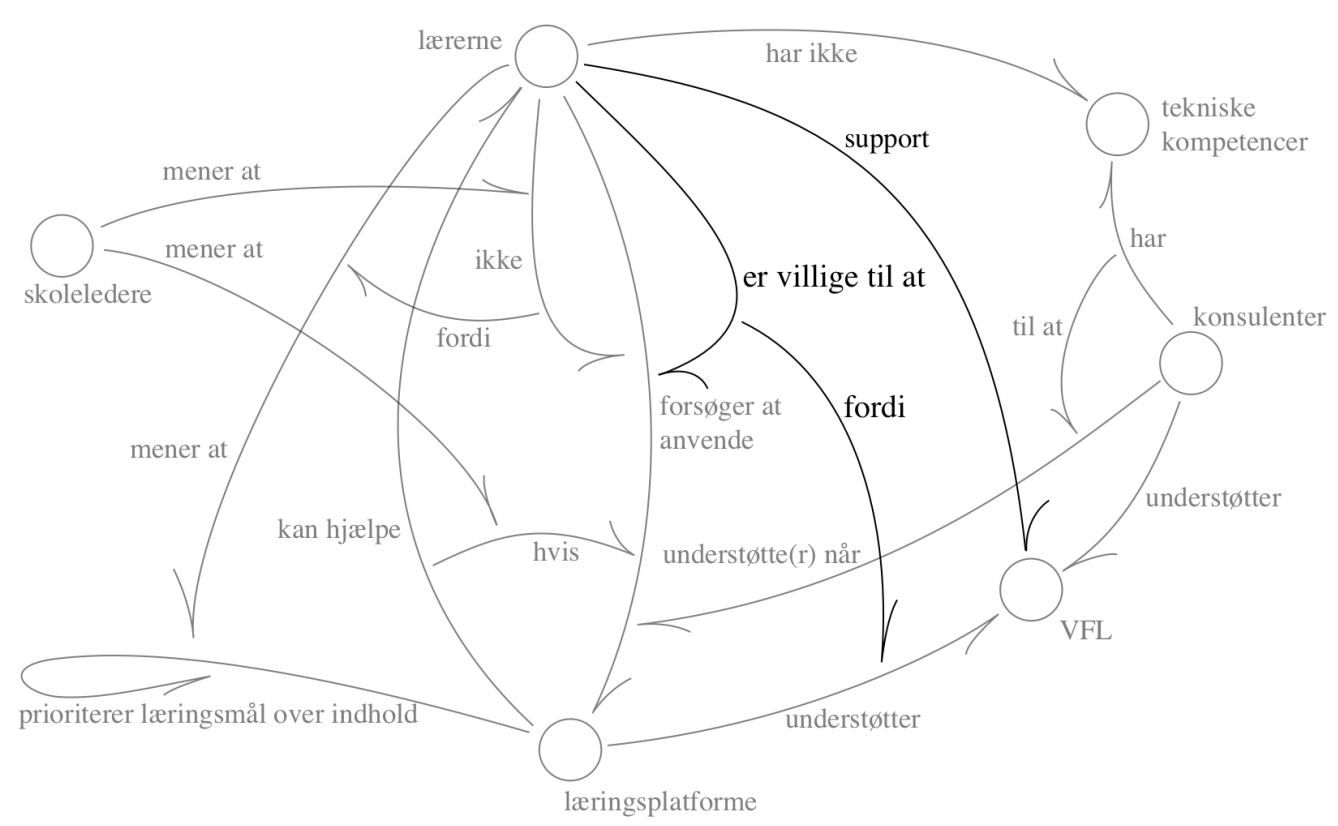

Som det er repræsenteret i Figur 5 ovenfor, havde lærerne imidlertid begrænsede tekniske kompetencer til at bruge platformen, hvilket fremgår af følgende observation, der blev nedfældet under fremtidsværkstedet:

99

Lærerne er meget i tvivl om, hvad læringsplatformene egentlig kan, og hvordan de kan bruge platformenes funktioner i det forløb, de vil afprøve. Der er tendens til, at samtalerne under workshoppen er fokuseret på konsulenten, fordi det er ham, der ved, hvordan platformen fungerer.

For at denne velvilje skulle udmønte sig i konkrete initiativer, var lærerne således afhængige af at samarbejde med den kommunale konsulent, der besad de kompetencer, de havde brug for. Dette vil vi vende tilbage til senere i artiklen. 


\section{Analyse: Kulturelle logikker blandt aktører og relationer mellem dem på de to skoler}

Repræsentationerne ovenfor tilvejebringer relativt overskuelige syntetiseringer af stabile mønstre i aktørernes måder at forholde sig til læringsplatformene på de to skoler. I det følgende vil vi gennem Nielsens (2012) begreb, kulturelle logikker, fokusere på at undersøge de bevæggrunde og prioriteringer, der ligger under de forskellige aktørers måder at forholde sig til platformene på. I det følgende vil vi gennemføre disse analyser separat på de to skoler for, på baggrund deraf, at diskutere betydningen af relationen mellem aktørers måde at forholde sig til platformene for implementeringen af dem.

\section{Skole 1}

Som det fremgår af visualiseringerne, betragter skolelederne på Skole 1 overordnet platformen som en teknologi, der kan spare lærerne for tid, hvis de investerer i at lære den at kende. Fra dette perspektiv blev lærernes bekymringer og kritik af læringsplatformene således betragtet som en konsekvens af deres begrænsede praktiske erfaring med platformene og deres manglende villighed til at prøve dem. Dette synspunkt giver således indblik i en kulturel logik, hvor platformen hovedsageligt antages at have indflydelse på hastigheden og effektiviteten af lærernes arbejdsprocesser, der fra ledernes synspunkt er det væsentligste (eller i hvert fald væsentlig).

Lærerne fra denne skole udviste imidlertid utilfredshed med læringsplatformen, fordi de oplevede, at den afkrævede dem at definere læringsmål forud for hver lektion. For læreren var dette problematisk, fordi det indebar, at de præcis skulle forudsige, hvordan eleverne ville deltage i undervisningen og interagere med det faglige indhold. Fra lærernes synspunkt ville dette fratage dem muligheden for at forfølge uventede og uforudsete måder at involvere sig i det faglige indhold blandt eleverne. Fra lærernes perspektiv truede læringsplatformenes fokus på opstilling af læringsmål dermed deres pædagogiske værdier og i et vist omfang også deres oplevede mulighed for at tilpasse undervisningen de behov og interesser, der måtte opstå. Disse synspunkter giver indblik i en kulturel logik orienteret mod at opretholde bestemte poedagogiske voerdier og tilgange til undervisning. Modsat af, hvad der var tilfældet i skoleledernes kulturelle logik, opfattes platfor- 
men blandt lærerne at ændre på karakteren af deres pædagogiske arbejde, ikke blot hastigheden eller effektiviteten af det.

\section{Relationen mellem de kulturelle logikker på Skole 1}

Som det fremgår af analyserne ovenfor, har lærerne og skolelederne grundlæggende forskellige syn på, hvad læringsplatformene gør, og især på relationen mellem platforme og undervisning. Lederne, der vægter effektive arbejdsprocesser, ser muligheder for, at platformene kan lette lærernes arbejde og give dem mulighed for at drage større nytte af hinanden, da platformene fx gør det muligt at dele forløb digitalt. Lærerne, der vægter pædagogik og didaktik, ser platformen som en snæver didaktisk ramme, som indskrænker deres pædagogiske handlerum. De kulturelle logikker mellem disse aktørgrupper støder således sammen og skaber spændinger, der gør det vanskeligt at komme til enighed om beslutninger i implementeringsprocessen, fordi deres kulturelle logikker repræsenterer forskellige erfaringshorisonter, prioriteringer og mål.

En af de væsentlige udfordringer under fremtidsværkstedet var, at grundantagelserne forblev tavse. Diskussionerne mellem aktørgrupperne foregik derfor på overfladen af disse underliggende perspektiver på platformene, og aktørerne havde meget vanskeligt ved at nå til enighed om, hvordan de skulle arbejde med læringsplatformen.

\section{Skole 2}

På Skole 2 så det imidlertid anderledes ud. Konsulenten, der deltog i workshoppene på denne skole havde fungeret som en af de drivende kræfter i implementeringen af VFL, som alle skoler i denne kommune havde taget i brug, og som konsulenten af denne denne årsag var optaget af at fastholde. Konsulentens kulturelle logik var således først og fremmest rettet mod at bevare en eksisterende pædagogisk tilgang, der allerede fungerede på skolen. Lærerne på denne skole delte dette ønske og mål og havde således en kulturel logik, der var samstemmende med den kommunale konsulent. Begge parter var enige om, at interventionen på skolen skulle afsøge muligheden for at integrere arbejdet med VFL i platformen. Denne enighed blandt parterne skabte gunstige betingelser for samarbejdet mellem konsulenten og lærerne, som lærerne var afhængige af, da de ikke havde de fornødne tekniske kompetencer til at gennemføre dette arbejde. 


\section{Relationen mellem de kulturelle logikker på Skole 2}

På denne skole var der således samstemmighed mellem de kulturelle logikker blandt lærerne og de kommunale konsulenter. Begge aktørgrupper delte det synspunkt, at det var pædagogiske principper, der skulle drive arbejdet med platformen, ligesom der var enighed blandt aktørerne om, hvilket pædagogisk princip, der skulle være drivende; VFL. I dette tilfælde fremstår VFL således som det fælles udgangspunkt, der gjorde det muligt for lærerne at drage nytte af og lære af konsulenternes tekniske viden om platformene. Under fremtidsværkstedet havde dette den indvirkning, at diskussionerne på denne skole var meget fokuserede, fordi aktørerne fremsatte og vurderede forslag og argumenter ud fra samme mål. Et afgørende aspekt ved aktørgrupperne på denne skole var, at der var etableret en didaktiske ramme, der samlede og retningsgav samarbejdet mellem dem.

Selvom lærerne var villige til at afprøve mulighederne for at understøtte VFL med platformene, og konsulenterne havde stærk viden om platformenes funktionalitet, oplevede lærerne vanskeligheder med at få platformen og VFL til at spille sammen. I sidste ende førte dette til, at skolen fravalgte at bruge evalueringsfunktionen indbygget i platformen. Dette understreger en anden vigtigt pointe, nemlig at fælles didaktiske principper også kan fungere som et kompas for informerede fravalg af de dele af platformen, som ikke understøtter skolens pædagogiske og didaktiske visioner.

Eksemplerne fra de to skoler viser, hvordan forskellige kulturelle logikker blandt centrale aktører på skoler skaber forskellige betingelser for implementering af læringsplatforme. Vores analyse af Skole 1 identificerede, at disse forskellige syn forårsagede et sammenstød mellem de kulturelle logikker. Dette forskød diskussionen fra at handle om, hvordan læringsplatformene kunne bringes hensigtsmæssigt i spil i lærernes undervisning til i stedet at handle om, hvorvidt lærerne prøvede at bruge platformen eller ej. Her stødte det pædagogiske personale og ledelsen således sammen. På Skole 2 havde det pædagogiske personale og den kommunale konsulent derimod en fælles didaktisk ramme, som eksperimenterne med læringsplatformene kunne forankres i, og som gjorde det muligt for konsulenten at bidrage konstruktivt med sin viden. På denne skole udfoldede der sig således et fælles mulighedsrum for at afsøge muligheden for at videreudvikle en didaktisk praksis.

Af årsagerne beskrevet ovenfor havde de to skoler ganske 
forskellige udgangspunkter for at arbejde med implementeringen af læringsplatformene, hvilke ledte til forskellige mulighedsbetingelser for at implementere platformen. I det følgende afsnit vil vi diskutere forudsætningerne for konstruktive dialoger og succesfulde implementeringer af læringsplatforme, og hvordan pædagogisk personale, skoleledere og kommunale konsulenter kan medvirke til at skabe de rette forudsætninger.

\section{Diskussion og konklusion}

Analyserne ovenfor viser, at konstruktive diskussioner, dialoger og eksperimenter med læringsplatformene i implementeringsprocessen forudsætter, at aktørerne på skolerne er orienteret mod fælles italesatte mål. På sin vis er det naturligt, at ledelse og pædagogisk personale orienterer sig mod forskellige mål, fordi de varetager forskellige typer af opgaver under forskellige hensyn, og de to parter navigerer i hver deres position i skolen som organisation. På de to skoler er der imidlertid en række forhold, som er nødvendigt for parterne at diskutere og i et vist omfang at nå til enighed om, hvis de skal nå til enighed i beslutninger om implementering og brug af platformen. Af analyserne tegner der sig et billede af, at det er vigtigt, at aktørerne på skolen har fælles forståelse af relationen mellem platforme og undervisning, og at det er en væsentlig fordel for implementeringsprocessen at basere beslutninger om implementering af platforme på italesatte pædagogiske og didaktiske mål. På Skole 1 har lærerne og skolelederne grundlæggende forskellige perspektiver på relationen mellem platformen og undervisning, og det er forskelle mellem disse synspunkter, der er kernen i uenigheden mellem de to parter. Mens skolelederne overvejende betragter platformen som en teknologi, der effektiviserer, betragter lærerne den som en teknologi, der ændrer rammerne for deres pædagogiske arbejde. Det betyder, at de to aktørgrupper orienterer sig mod forskellige mål i implementeringsprocessen, hvilket kommer til udtryk i uenigheder. Udfordringen på Skole 1 består ikke nødvendigvis $\mathrm{i}$, at parterne har forskellige perspektiver på relationen mellem platformen og undervisning, men i at konfliktens kerne på intet tidspunkt italesættes, og at diskussionerne således foregår på overfladen af roden til uenighederne. Parterne på denne skole diskuterer således spørgsmål om, hvorvidt lærerne burde anvende platformen uden at diskutere, hvilke mål platformen bør indfri. I tilfældet på Skole 1 betyder disse uoverensstemmelser, 
at det er vanskeligt at implementere læringsplatformene succesfuldt.

På Skole 2 er der enighed blandt parterne om, hvad der vægtes; VFL er det vigtigste, og der er enighed om, at platformens rolle bør være at understøtte det fortsatte arbejde med dette pædagogiske princip. Dette skaber et fælles udgangspunkt for at diskutere, eksperimentere og vurdere udfaldet af eksperimentet, som sidenhen kan danne udgangspunkt for beslutninger i implementeringsprocessen.

Som vi tidligere har fremført, viser studier, at aktørgrupper oplever bekymringer i forhold til forestående implementering af læringsplatforme (Lochner, Conrad \& Graham, 2015). Analyserne i nærværende artikel viser, at en del af disse bekymringer blandt lærere kan være relateret til, at læringsplatforme ikke betragtes som pædagogiske og didaktiske neutrale teknologier, der blot rummer muligheder for at lette læreres arbejde. I implementeringsprocessen er det afgørende, at sådanne synspunkter bliver hørt, og at pædagogiske argumenter for, hvordan og i hvilket omfang læringsplatformen skal eller ikke skal anvendes, får vægt. Det er et velkendt faktum, at det er vigtigt at inddrage lærere i implementeringen af nye teknologier. Denne pointe fremhæver imidlertid, at inddragelse af medarbejderne med fordel kan sigte mod at skabe fælles pædagogiske mål, som implementeringsprocessen skal arbejde på at forbinde platformene til. En sådan enighed fører imidlertid ikke nødvendigvis til en succesfuld implementering af platformene forstået som aktiv anvendelse af den. Læringsplatformene rummer mange forskellige funktioner, og i de fleste tilfælde er det kun realistisk for lærere at arbejde med et udvalg af disse. Uafhængigt af platformene arbejder de fleste skoler med pædagogiske og didaktiske tilgange, og Skole 2 viser, at der kan være potentialer i at forsøge at videreføre arbejdet med disse tilgange i platformene. Som vi så på Skole 2, kan en sådan tilgang skabe grundlag for diskussioner og beslutninger om, hvordan læringsplatformene kan bruges på hensigtsmæssige måder. Eksemplet på Skole 2 understreger imidlertid, at fælles kulturelle logikker blandt skolens aktører ikke nødvendigvis fører til en succesfuld implementering, da platformenes udformning ikke kan forenes med alle pædagogiske og didaktiske principper. På baggrund af Skole 2's oplevelser af ikke at kunne forene platformen med VFL, valgte de som bekendt at undlade at bruge platformen. Dette viser nødvendigheden af at basere beslutninger om brug af platformen på didaktiske og pædagogiske 
overvejelser uafhængigt af platformen. Teknologier som læringsplatforme finder ofte deres vej ind i uddannelsessystemet og kan i nogle tilfælde føre til grundlæggende ændringer af undervisning og læring, hvis de adopteres af lærere. I sådanne situationer er det vigtigt, at skoler er opmærksomme på at sikre kvalitet i undervisningen. Analysen i denne artikel viser, at tydeligt italesatte pædagogiske værdier som på Skole 2 kan fungere som kulturelle logikker, der understøtter skoler i at træffe informerede beslutninger om, hvordan, i hvilket omfang og om disse teknologier i det hele taget skal anvendes i undervisning. I den forstand kan ensrettede kulturelle logikker skabe et refleksivt handlerum, hvor skoler kan navigere i valget af tilgængelige teknologier på et informeret og kvalificeret grundlag defineret af dem selv.

I denne artikel har vi arbejdet mod at besvare følgende forskningsspørgsmål:

Hvilke kulturelle logikker kan der identificeres blandt aktørerne på fremtidsvoerkstederne, og hvilke implikationer har disse logikkers indbyrdes relation for betingelserne for den lokale implementering af loeringsplatformene?

I artiklen har vi vist, at skolelederne på Skole 1 er orienterede mod optimering og effektivisering af arbejdsprocesser, men at lærerne på denne skole i højere grad er orienterede mod at bevare et pædagogisk handlerum. De kulturelle logikker blandt aktørerne er således orienteret mod forskellige mål, hvilket gør det vanskeligt for parterne at nå til enighed i beslutninger om implementering af platformene. På Skole 2 var begge de deltagende aktørgrupper imidlertid indstillet på at bevare et etableret pædagogisk og didaktisk princip, der skabte gunstige betingelser for implementering af platformene. Artiklen giver således indblik i de årsager, der kan være roden til lokale vanskeligheder i relation til implementering af platformene og peger på vigtigheden af at definere fælles mål uafhængigt af platformen, der kan fungere som styringsprincip i beslutninger om, hvordan, i hvilket omfang, og om platformene skal bruges. Denne viden er vigtig i implementering af platformene, fordi den tydeliggør vigtigheden af at holde fast i, at målet med at implementere platformene ikke blot er at bruge dem, men at bruge dem på måder, der kvalificerer undervisning og læring. 


\section{Referencer}

Allsopp, B. B. (2013). Introducing Arc Form: Designing a satisfactory highly non-linear alternative to texts for general-purpose idea development (ph.d.afhandling). København: Institut for Uddannelse og Pædagogik, Aarhus Universitet.

Edmunds, B. \& Hartnett, M. (2014). Using a Learning Management System to Personalise Learning for Primary School Students. Journal of Open, Flexible and Distance Learning, 18(1), 11-29.

Kommunernes Landsforening. (2014). Aftale om konkretisering af det foelles brugerportalsinitiativ for folkeskolen. København: Kommunernes Landsforening.

Liu, F. \& Cavanaugh, C. (2011). High Enrollment Course Success Factors in Virtual School: Factors Influencing Student Academic Achievement. International Journal on E-Learning, 10(4), 393-419.

Lochner, B., Conrad, R. \& Graham, E. (2015). Secondary Teachers' Concerns in Adopting Learning Management Systems: A U.S. Perspective. TechTrends: Linking Research and Practice to Improve Learning, 59(5), 62-70. https://doi.org/10.1007/s11528-015-0892-4

Lu, J. \& Law, N. W. Y. (2011). Understanding Collaborative Learning Behavior from Moodle Log Data. Interactive Learning Environments, 20(5), 451-466. https://doi.org/10.1080/10494820.2010.529817

Misfeldt, M. (2016). Digitalt Understøttede Loeringsmål: Udviklingsprojekt med demonstrations-skoleforsøg vedr. it i folkeskolen (Slutrapport) (1. udg.). København: Institut for Læring og Filosofi, Aalborg Universitet.

Misfeldt, M. \& Tamborg, A. L. (2016). Læringsmålstyret undervisning og målforståelser - statiske og dynamiske mål. Cursiv, 19, 113-139.

Nielsen, L. T. (2012). Teamsamarbejdets Dynamiske Stabilitet. En Kulturhistorisk Analyse Af Loereres Loring i Team (ph.d.-afhandling). Aarhus: Aarhus Universitet.

Psycharis, S, Chalatzoglidis, G. \& Kalogiannakis, M. (2013). Moodle as a Learning Environment in Promoting Conceptual Understanding for Secondary School Students. EURASIA Journal of Mathematics, Science $\mathcal{E}$ Technology Education, 9(1), 11-21.

Slemmen, T. (2016). Vurdering for loering i klasserummet. Frederikshavn: Dafolo.

Selwyn, N. (2012). "It's All about Standardisation"-Exploring the Digital (Re) Configuration of School Management and Administration. Cambridge Journal of Education, 41(4), 473-488.

DOI: 10.1080/0305764X.2011.625003

Tamborg, A. L, Allsopp, B. N., Fougt, S. S. \& Misfeldt, M. (2017). Mapping the logics in Practice Oriented Competence Development. Proceedings of CERME10, Dublin, februar 2017 (s. 3873-3880). Dublin: HAL.

Underwood, J. D. \& Stiller, J. (2013). Does Knowing Lead to Doing in the Case of Learning Platforms? Teachers and Teaching: Theory and Practice 2O(2), 229-246. https://doi.org/10.1080/13540602.2013.848569. 
Learning Tech - Tidsskrift for læremidler, didaktik og teknologi Udgives af Læremiddel.dk

Learning Tech er et forskningstidsskrift, hvor alle artikler er forskerbedømt i form af dobbeltblindt peer review. Tidsskriftet bringer artikler, der rammer genstandsfeltet mellem læremidler, didaktik og teknologi, og hensigten er at spille en betydelig rolle som platform for den voksende skandinaviske læremiddelforskning.

\section{Redaktion}

Stig Toke Gissel, UCL Erhvervsakademi og Professionshøjskole (ansvarshavende redaktør)

Bettina Buch, Professionshøjskolen Absalon

Hildegunn Juulsgaard Johannesen, University College Syd

René Boyer Christiansen, Professionshøjskolen Absalon

Stine Reinholdt Hansen, UCL Erhvervsakademi og Professionshøjskole

Thomas R.S. Albrechtsen, University College Syd

\section{Redaktionssekretær}

Trine Ellegaard, UCL Erhvervsakademi og Professionshøjskole

\section{Temaredaktion}

Ane Qvortrup, Syddansk Universitet

Stig Toke Gissel, UCL Erhvervsakademi og Professionshøjskole

Morten Misfeldt, Aalborg Universitet

Jens Jørgen Hansen, Syddansk Universitet

\section{Design og grafisk tilrettelæggelse}

Trefold - grafisk design og kommunikation

\section{Tryk}

Narayana Press, Gylling

ISSN 2445-7981 (Tryk)

ISSN 2445-6810 (Online)

\section{Rettigheder}

(C) 2019 Læremiddel.dk og forfatterne

\section{Kontakt}

Læremiddel.dk, Niels Bohrs Allé 1, 5230 Odense M

https://learningtech.laeremiddel.dk

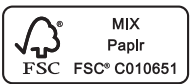

